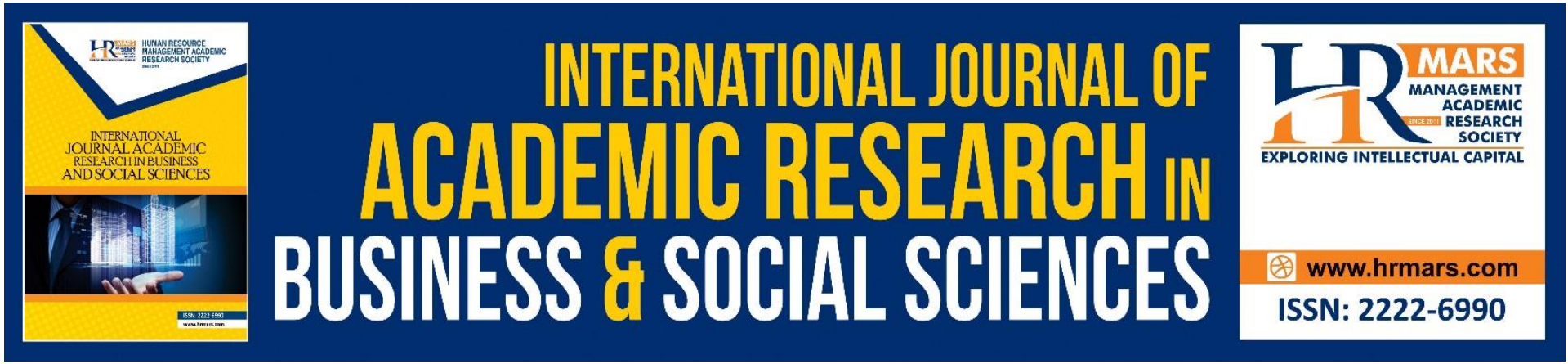

\title{
The Relationship Between Language and Religion
}

\section{Belinda Marie Balraj, Surjeet Singh, Masdini Harina Abd Manan}

To Link this Article: http://dx.doi.org/10.6007/IJARBSS/v10-i11/8198

DOI:10.6007/IJARBSS/v10-i11/8198

Received: 14 September 2020, Revised: 01 October 2020, Accepted: 05 November 2020

Published Online: 26 November 2020

In-Text Citation: (Balraj, Singh, \& Abd Manan, 2020)

To Cite this Article: Balraj, B. M., Singh, S., \& Abd Manan, M. H. (2020). The Relationship Between Language and Religion. International Journal of Academic Research in Business and Social Sciences. 10(11), 1217-1224.

Copyright: (c) 2020 The Author(s)

Published by Human Resource Management Academic Research Society (www.hrmars.com)

This article is published under the Creative Commons Attribution (CC BY 4.0) license. Anyone may reproduce, distribute, translate and create derivative works of this article (for both commercial and non-commercial purposes), subject to full attribution to the original publication and authors. The full terms of this license may be seen at: http://creativecommons.org/licences/by/4.0/legalcode

Vol. 10, No. 11, 2020, Pg. 1217 - 1224

http://hrmars.com/index.php/pages/detail/IJARBSS

JOURNAL HOMEPAGE

Full Terms \& Conditions of access and use can be found at http://hrmars.com/index.php/pages/detail/publication-ethics 


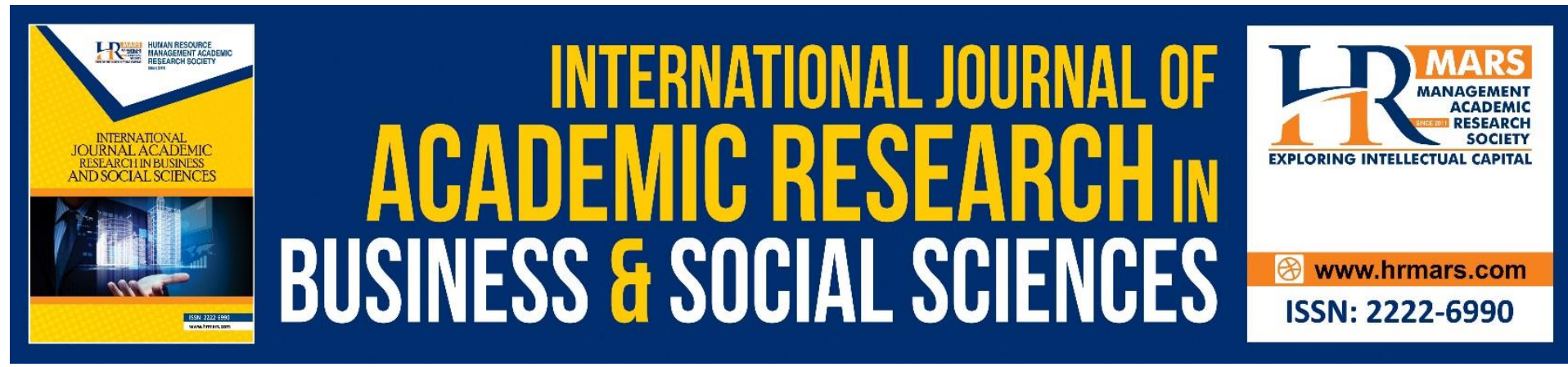

\title{
The Relationship Between Language and Religion
}

\author{
Belinda Marie Balraj, Surjeet Singh, Masdini Harina Abd Manan \\ National Defence University of Malaysia, Malaysia
}

\begin{abstract}
Language is the most powerful means of communication, a vehicle of expression of cultural values and aspirations and instrument of conserving culture. As such language is an important means to acquire and preserve the identity of a particular group or community. This also affects how linguistic conflict plays a role in religious conflict and how it is manipulated by certain groups. We have to use language in the positive sense to manage socio-cultural, linguistic, religious and political needs of the world. The paper therefore highlights that language and religion have to be used in a positive manner especially in Malaysia which is a multi-racial country.
\end{abstract}

\section{Introduction}

Language is the most powerful means of communication, vehicle of expression of cultural values and aspirations and instrument of conserving culture. As such language is an important means to acquire and preserve the identity of a particular group or community. Among the various cultural symbols - religion, race, language, traditions and customs, etc. that differentiate an ethnic group from the other, language is the most potent cultural marker providing for group identity. Its spatial spread over a fixed territory makes language more important than religion as a basis of ethnic identity formation.

Language and culture are interrelated because the language regions possess certain homogeneity of culture and are characterized by common traits in history, folklore and literature. Neglecting one's cultural heritage, of which language is a vital component, deprives a community of a most valuable source of spiritual sustenance without which no creative activity can be undertaken whether in the realm of arts or science. Furthermore; the neglect erodes the community's confidence in its ability to perform. By bringing up a generation ignorant of its language, a community gradually loses its roots and religious values (Adeosun, 2011).

Although all societies have some kind of religion, their answers to life's questions do not form a single body of knowledge. Religion is not a discipline, like science, that steadily provides new knowledge, filling in our picture of the world. In some cases, religion is opposed to science because it is rooted more strongly in belief than in reason (Adeosun, 2011). The truths of religion cannot be measured or counted because we cannot stand outside of religion to study it.

Generally as language changes, so religion changes. This may not be the case for Islam as there is a direct relationship between the Arabic language and Islam. The Qur'an and the Hadith are in Arabic and this has led to Arabic being given significant prominence in the study 
of Islam; since the ultimate aim is to protect the Qur'an from wrong understanding of the message. However the above maxim is quite true for other religions such as Hinduism which was originally in Sanskrit but now in the vernacular languages and Christianity, from Hebrew to the English language.

The main aim of this paper is to discuss the relationship between language and religion. This ultimately brings in the topic of culture as all these three topics are very much interrelated. A discussion of the role of language and religion in society and how language is used to portray religion will also be covered. Furthermore how linguistic conflict affects religious conflict and how language is manipulated politically by various races will be given prominence. Lastly the researcher will also discuss feminist language in religion culminating in a discussion of how language and religion are manipulated for the advantage of the third party.

\section{The Role of Religion in Society}

Religion has a profound impact on any society or culture. Although some people say that religion is a private matter, it cannot be put into a "straitjacket" as religion is a social issue and involves other people. We might say, therefore that religion is a community's response to what it experiences as sacred. That response is typically in the form of shared beliefs, prayers, rituals and codes of behavior.

All people know the world only from their own limited points of view. But nearly all people believe that an unconditioned reality - infinite, external and absolute must also exist. Such an unconditioned reality goes by many names such as God, Allah, Jesus, Tao, Brahman, the Great, or Mysterious Spirit. Religions have always arisen, and they continue to arise from specific places, people and problems. Each religion has a particular history and way of looking at the world (Goldman, 1995; Gavra \& Peristeropoulou, 2013). In this way religions are much like languages with distinct qualities, histories, and points of view. Languages grow as cultures change and so do religions. A conquering army may impose a new language and or religion on the vanquished people.

There is another more dangerous, way in which religions are like languages. Just as speakers of one language often misunderstand speakers of another language, followers of one religion may find another one comical or grotesque. Similarly, as people who speak one language may exclude people who do not, followers of one religion may use religious differences as a reason to dislike or distrust followers of another religion (Harris, 2013). Thus, our inability to understand one another may magnify our differences.

\section{Use of Language to Portray Religion}

Language has been one of the main means to portray a religion. Of course other means such as religious customs, symbols and chants have been used. However for a religion to survive among the coming generations, it has to be communicated and this is where language plays its role. Here the researcher will discuss four main religions and the use of language in the respective religions.

In Islam, Muslims have paid a great attention to the study and analysis of the Arabic language as they developed linguistic studies for the purpose of Qur'anic recitations, thus understanding and protecting the external constitution of the Muslim Ummah (Peterson and Others, 1996). According to Al-Attas, the Islamised Arabic is elevated as the language in which God revealed the Holy Qur'an to mankind. Al-Attas views that Islamic Arabic is perfected to the superlative degree as it is not subjected to change and development as compared to other languages which derive from culture and tradition (Peterson and Others, 2009). 
However this has not been the case for Christianity and Hinduism. In Christianity, Hebrew was the original language as well as the holy language. It was widespread in Jewish religious literature and is widely believed by Orthodox Jews. Over time and with the spread of Christianity, the lingua franca became English. Ironically English is the most widely used language in the world today.

In the case of Hinduism, Sanskrit stood for three millennia as the carrier of Vedic thought before its dominance gradually gave way to numerous vernacular dialects that eventually evolved into modern day languages of Hindi, Guajarati, Bengali, Tamil, Telugu, Kannada and so on Smith (1991). While the shift from Sanskrit to these regional languages forced a change in the meaning of words, the shift was at least within the context languages that were closely related to Sanskrit. As Hinduism expands in the West, the emerging forms of ancient traditions are naturally being reflected though the medium of Western languages, most prominent of which is English.

The same problem is being faced by Sikhism as the youths of today are becoming more Westernized and are not learning the Gurmukhi script, the script in which the holy book, the Guru Granth Sahib is written (Aziz, 2001). So many youths know the Punjabi language but not the Gurmukhi script. Thus, they tend to rely on English for translation and at times the subtle meaning is lost. The situation is further worsened by families whose parents themselves do not speak Punjabi at home (Aziz, 2001). Thus, the children speak English and Malay only.

\section{Language, Religion and Conflict}

At times linguistic conflict can lead to religious conflict. This is especially true in India where the government has made Hindi the national language. Tamil Nadu, a state in the south initially refused to accept Hindi as the national language and wanted Tamil to be the national language. Although the North and South is dominated by Hindus, they do not see 'eye to eye' on many issues and insist on carrying out their religious obligations in their own vernacular languages.

The experience in Punjab is the same, where Hindus though speaking Punjabi at home earlier claimed Hindi as their mother tongue during the census operations. Similarly, is the case with Muslims of Uttar Pradesh, who registered their language as Hindustani in the 1951 Census but have been claiming Urdu as their mother tongue subsequently (Aziz, 2001). This demonstrates the urge of Muslims in other Indian states to identify themselves with Urdu rather than Hindustani or the indigenous mother tongues in a bid to consolidate themselves as a distinct collective group linked together by common bond of religion and Urdu which they believe to be representing their Muslim cultural identity.

Language, religion and history divide Serbs and Albanians in Kosovo. A patch of land not much larger than Israel - this is what Kosovo's Serbs and ethnic Albanians have in common. They speak different languages, have different religious beliefs and give different accounts of their history. The ethnic Albanians speak a language belonging to the IndoEuropean language family - one as ancient as Latin. The language spoken by the Serbs is Slavonic.

Since the 1980's the ethnic Albanians have boycotted the educational system in Kosovo, in favour of their own schools funded by Albanians living abroad. As a result, a great number of the Albanians do not know the Serb language; at the same time, only few of the Serbs have learnt Albanian. Most of the ethnic Albanians are Muslims, successors of Catholic and Orthodox Christians who had adopted Islam during the 500 yearlong Ottoman rule. The Serbs are staunch Orthodox Christians and observe the Christian tradition. The situation is 
further complicated by efforts to regain official language status for Turkish in Kosovo. Upon reactions of both Turks living in Kosovo and the Turkish government, the UN Mission in Kosovo (UNMIK) has reversed a previous decision and stated that it would establish some regulations for Turkish to be acknowledge Turkey ruled Kosovo for hundreds of years during the Ottoman Empire and has strong emotional ties to ethnic Turks who remained in the area after the Ottoman Turks retreated in 1912 (Goldman, 1995).

\section{Language and Politics}

As the old saying goes: 'The pen is mightier than the sword'. Language is manipulated by the political powers to sow seeds of discord among religious groups in order to always have the upper hand. This has been practiced from time immemorial starting from the British who used the policy of 'Divide and Rule' to the Americans of the present day with their slogan 'Weapons of Mass Destruction - WMA' in Iraq. The British have used religion to divide the people of the Indian sub-continent culminating in the creation of two separate countries, India and Pakistan. Even in the Middle East the ploy of religion was used to create Israel, resulting in the Palestinians being 'homeless' and 'without a country to call their own. The Americans went into Iraq manipulating phrases such as WMD and using notions that they were 'liberating' the Iraqis from Saddam's hegemonic rule.

In Malaysia, Parti Islam Malaysia (PAS) used the word 'Islam' to sway rural votes in their favour. They really play the issue of religion especially among Muslims in order to beat the ruling government party, Barisan National, in the elections. Every small issue is connoted to the ruling party being un-Islamic. However, what they must understand is that Malaysia is a multi-racial country and using religion can stir emotions which may lead to religious riots (Harris, 2013). So, the issue of religion should not be harped upon for the good of the country - economically and politically.

\section{Language and Power}

George W. Bush has used emotional language especially negatively charged emotional language as a political tool to connote power of the presidency. Although he is generally regarded as a mangler of the English language, Bush, like many dominant personality types, uses dependency - creating language. He employs language of contempt and intimidation to shame others into submission and desperate admiration.

While we tend to think of the denominator as using physical force, in fact most denominators use verbal abuse to control others. Bush uses several dominating linguistic techniques to induce surrender to his will. They are:

a. Empty language - refers to broad statements that are so abstract and mean so little that they are virtually impossible to oppose.

b. Personalization - localizing the attention of the listener on the speaker's personality eg. Using the word 'I'.

c. Negative framework - giving a pessimistic image of the world. eg. referring to 9/11. In fact, Bush is playing dangerous religion by adding the word God - and that changes the picture dramatically. As 'Christian Today' put it, "some worry that Bush is confusing genuine faith with national ideology". President Bush uses religious language more than any president in U.S. history and he must take into consideration of the quotations below.

'Religion is the most dangerous energy source known to humankind. The moment a person (or government or religion or organization) is convinced that God is either 
ordering or sanctioning a cause or project, anything goes. The history worldwide, of religion-fueled hate, killing and oppression is staggering.

(Eugene Peterson, The Message)

Even Islam faces this same problem. The problem with the current spate of terrorism is that those involved in it are of the opinion that they are on an Islamic Jihad - a holy war - to rid the evil perpetrators ie Israel and USA, its staunch supporter. To complicate matters, strict imitation of Prophet Mohammed is considered the highest achievement in Islamic fundamentalism, particularly in the cause of the Jihad. Furthermore, at times the modern fundamentalists give their own interpretations of the Qur'an and Hadith to suit their brand of politics and administration. This may be shown by the interpretation of the two Surah below which practiced literally, the prophet's words include some very dangerous premises.

"Warfare is ordained for you, and this an object of dislike to you; and it may be that you dislike a thing while it is good, good for you, and that it may be that you love a thing while it is evil for you, and Allah knows, while you do not."

(Surah Al-Baqarah 2.216)

So, it can be seen that when politicians and religious leaders start quoting the Bible or the Qur'an, the general public gets mesmerized with their own interpretation which may be completely against what it was intended to portray. A layman's view can become very dangerous as an 'idle mind is a devil's workshop' and society generally suffers.

\section{Feminism and the Language Wars of Religion}

Another interesting aspect in the whole world is the rise of feminism and feminists want their views to be considered and heard in every aspect of life. Well then religion is no stranger to them. Why do feminists want to control human communication? Because language is the means by which we transmit the culture from one generation to the next. Why stop this?

Feminist language, this insidious aggressive form of mind bending has now permeated the entire English - speaking world, but its most devastating effects have been felt in the academy and in the churches - for the very good reason that both are primary storehouses as well as transmitters of moral and ethical principles and religious beliefs (Hitchcock, 2007). Most Catholics are aware that the English translation of the historic Catechism of the Catholic Church, the first in four hundred years, was delayed for over a year to correct an inaccurate translation - not incorporating feminist language. One of the problems we have with confronting feminism at present time is that so many variations of feminism have developed during the past three decades. Another reason why it is so hazardous to attempt any critique whatsoever of any aspect of feminism or the feminist agenda is that the critic, whether a man or a woman, will automatically be accused of opposing the equality and dignity of women. This is clearly stated in Sister Sandra's 1991 book, Beyond Patching (Campbell, 2003).

'Feminism engages in a focused social analysis which has revealed the role of patriarchy not only as the root of women's oppression but also as the source of interconnectedness of sexism with all other forms of hierarchical domination.'(p.33)

Scripture has not only been interpreted wrongly by men to further oppress women but, according to Sister Sandra, is

'A male centred account of male experience for male purposes with women relegated to the margins of salvation history, but also is patriarchal in its 
assumptions deeply sexist, ie anti-women. Its God - language and imagery are overwhelmingly male. the problem is in the text.' (p. 38)

At the same time, there has been some members of the Clergy who are against too much feminism being brought into the Church because it ultimately changes the Holy Bible. One important thing that happens when a language is tampered with is the disruption of a kind of cultural, collective or universal, Catholic memory.

\section{Conclusion}

Language can be used as a double - edged knife to portray religion. One aspect is to use it to portray the righteousness of religion, sacred devotional, doing justice and good to mankind, and uplifting morality. The other aspect is to manipulate language for personal and political needs - using bad theology to confuse the public, nation and the religious institutions.

A classic example in Malaysia would be the Tanjung Piai By - Election 2019 where the statement by both Barisan Nasional (BN) and Pakatan Harapan (PH) agreed that issues on race and religion will not be entertained during nomination day. However, as the election progresses, both sides have been bringing in the issues of race and religion, hoping that it will give them leverage (The Sub, 2019).

What we must understand is that the globalized world is becoming smaller and smaller. What mankind needs is peace and harmony as against deceit and treachery. The best solution will be to respect all religions and keep religion away from politics. However, this is easier said than done. We have to use language in the positive sense to manage socio-cultural, linguistic, religious and political needs of the world. Leaders must not manipulate language especially religious language as it can lead to a battle off civilizations and perhaps to the end of the world.

\section{Corresponding Author}

Belinda Marie Balraj, National Defence University of Malaysia, Malaysia.

Email: belinda@upnm.edu.my

\section{References}

Adeosun, A. B. (2011). Federal character principle and national integration: A critical appraisal. International Journal of Politics and Good Governance, 2(2.4), 1-13

Airtchison, J. (2013). Language Change: Progress or Decay. 4th Edition.Canmbridge

Fromkin, V., \& Rodman, R. (2013). An Introduction to Language. Fort Worth: Harcourt Brace College Publishers.

Gavra, E. G., \& Peristeropoulou, D. C. (2013). Ekistic Heritage and Enhancement; The Case of Sulina. Multilingual Academic Journal of Education and Social Sciences, 1(1), 39-49.

Goldman, E. (1995). Believers - Spiritual Leaders of the world. New York: Oxford University Press.

Harris, R. (Ed) (2013). Language and Intelligence, Gamlingay, Authors Online Ltd.

Smith, H. (1991). The Worlds Religions. New York: Harper Collins.

Ahmad, A. - ud - D. (2001). In Support of Punjabi Language. http://www..apnaorg.com

Brooks, R. 2003. Focus: Power of presidency resides in language as well as law. http://www.nwsource.com

Campbell, A. (2003). Religion, Memes and Language. http://www.homepage.ntlworld.com

Chava, B. (20030. A War of worlds: Tradition, Language \& Religion. http://www.watch of the lord.com 
INTERNATIONAL JOURNAL OF ACADEMIC RESEARCH IN BUSINESS AND SOCIAL SCIENCES Vol. 10, No. 11, 2020, E-ISSN: $2222-6990$ ๑ 2020 HRMARS

Hitchcock, H. (2007). Feminism and Language Wars of Religion. http://www.adoremus.org/Feminism Language.html The Sun, 2019. November 11. 